\title{
Evaluation of the Effect of Consciousness Energy Healing Treatment on the Physicochemical and Thermal Properties of Silver Oxide
}

\begin{abstract}
Keywords: Silver oxide; The trivedi Effect ${ }^{\circledR}$; PXRD; PSA; DSC
Abstract

Silver oxide has many applications in the pharmaceuticals industry, but it is insoluble in many solvents and sensitive to light. The aim of this study was to evaluate the impact of the Trivedi Effect ${ }^{6}$ on the physicochemical and thermal properties of silver oxide using modern analytical techniques. The silver oxide test sample was divided into two parts, one part of the test sample was considered as a control sample, whereas the other part received the Biofield Energy Treatment remotely by a renowned Biofield Energy Healer, Alice Branton and termed as a treated sample. The PXRD peak intensities and crystallite size were significantly altered ranging from -37.33 to $17.89 \%$ and $-63.23 \%$ to $230.12 \%$, respectively; however, the average crystallite size was significantly decreased by $18.13 \%$ in the treated silver oxide compared with the control sample. The particle size values were significantly decreased by $36.02 \%\left(d_{10}\right)$ $26.15 \%\left(d_{50}\right), 23.46 \%\left(d_{90}\right)$, and $26.15 \%\{D(4,3)\}$, respectively; therefore, the specific surface area was significantly increased by $61.94 \%$ in the treated sample compared with the control sample. The latent heat of fusion of the treated silver oxide was significantly decreased by $43.29 \%$ compared with the control sample. The total weight loss was increased in the treated sample by $8.13 \%$ compared with the control sample. The Trivedi Effect ${ }^{\circledR}$-Consciousness Energy Healing Treatment introduced a new polymorphic form of silver oxide which may show better solubility, dissolution rate, absorption, and bioavailability of silver oxide in the pharmaceutical formulations and advantageous for the industry using it as a raw material.
\end{abstract}

\section{Introduction}

Silver oxide is a fine black or dark brown chemical compound. It is used as a reagent in the laboratory reactions to synthesize various compounds; as well as in organic chemistry as a mild oxidizing agent (i.e., oxidizes aldehydes to carboxylic acids), and in silver-oxide batteries. It is also impregnated in fabrics used in surgery as it resists the growth of microbes [1-3]. Local treatment with this silver oxide ointment, in difficult venous ulcerations, as one component of the total wound dressing, which improved microcirculation measurements and healing rate [4]. Silver oxide is very effective in removing carbon dioxide from the humidified air. This characteristic of silver oxide is extensively used in space missions (by the international space station, nuclear submarines, and space shuttle). Silver oxide nanostructure on porous silicon used for the optoelectronic application. For the preparation of pollution control filter for gas sensors silver oxide also used $[5,6]$. The physicochemical properties of silver oxide are photosensitive, decomposes at lower temperatures $\left(280^{\circ} \mathrm{C}\right)$, soluble in acid and alkali, slightly soluble in water, and insoluble in ethanol [1-3].
Journal of

Chemistry \& Applications

\author{
Branton $A^{1}$, Trivedi $M K^{1}$, Trivedi $D^{1}$, Nayak $\mathbf{G}^{1}$ and \\ Jana $\mathbf{S}^{2^{\star}}$ \\ ${ }^{\prime}$ Trivedi Global, Inc., Henderson, USA \\ ${ }^{2}$ Trivedi Science Research Laboratory Pvt. Ltd., India \\ Address for Correspondence \\ Snehasis Jana, Trivedi Science Research Laboratory Pvt. Ltd., Bhopal, India. \\ Tel: 91-022-25811234; Email: publication@trivedieffect.com \\ Submission: 21 September, 2018 \\ Accepted: 25 October, 2018 \\ Published: 7 November, 2018 \\ Copyright: (c) 2018 Branton A, et al. This is an open access article \\ distributed under the Creative Commons Attribution License, which \\ permits unrestricted use, distribution, and reproduction in any medium, \\ provided the original work is properly cited.
}

In this regards, the Trivedi Effect'-Biofield Energy Healing Treatment has a significant impact on the physicochemical properties of various living and non-living object(s) [7-9]. The Trivedi Effect is a natural and only scientifically proven phenomenon in which a person can harness this inherently intelligent energy from the Universe and transmit it anywhere on the planet through the possible mediation of neutrinos [10]. There is a unique para-dimensional electromagnetic field exists around the body of every living organism, which generated from the continuous movement of the electrically charged particles (ions, cells, etc.) inside the body is known as "Biofield" (Putative Energy Field). The Biofield based Energy Healing Therapies have been accepted worldwide and reported with significant outcomes against various disease conditions [11]. The National Institutes of Health (NIH) and National Center for Complementary and Alternative Medicine (NCCAM) recommend and included the Energy therapy under Complementary and Alternative Medicine (CAM) category along with homeopathy, Ayurvedic medicine, traditional Chinese herbs and medicines, naturopathy, Tai Chi, Qi Gong, chiropractic/osteopathic manipulation, Reiki, healing touch, yoga, meditation, massage, progressive relaxation, guided imagery, acupuncture, acupressure, movement therapy, hypnotherapy, pilates, Rolfing structural integration, mindfulness, cranial sacral therapy, aromatherapy, etc. The CAM has been accepted by most of the U.S. population [12,13]. The Trivedi Effect-Consciousness Energy Healing Treatment also gained huge achievements in different field of sciences which has been reported with amazing results, i.e., in agriculture [14, 15], microbiology [16,17], biotechnology [18,19], organic chemistry $[20,21]$, material science $[22,23]$, medical science $[20,21]$, and nutraceutical/pharmaceutical sciences [26,29]. Seeing the amazing results of the Trivedi Effect -Consciousness Energy Healing Treatment on various living and non-living object(s), this current study has been designed to evaluate the impact of the Trivedi Effect on silver oxide using Powder X-ray Diffraction (PXRD), Particle Size Analysis (PSA), Differential Scanning Calorimetry (DSC) Analytical Techniques, and Thermogravimetric analysis (TGA)/Differential Thermogravimetric Analysis (DTG). 
Citation: Branton A, Trivedi MK, Trivedi D, Nayak G, Jana S. Evaluation of the Effect of Consciousness Energy Healing Treatment on the Physicochemical and Thermal Properties of Silver Oxide. J Chem Applications. 2018;4(1): 5.

Table 1: PXRD data for the control and the Biofield Energy Treated silver oxide.

\begin{tabular}{|c|c|c|c|c|c|c|c|c|}
\hline $\begin{array}{c}\text { Entry } \\
\text { No. }\end{array}$ & $\begin{array}{c}\text { Bragg angle } \\
\left({ }^{\circ} 2 \theta\right)\end{array}$ & \multicolumn{3}{c|}{ Peak Intensity $(\%)$} & \multicolumn{3}{c|}{ Crystallite size (G, nm) } \\
\cline { 2 - 10 } & $\begin{array}{c}\text { Control } \\
\text { Treated }\end{array}$ & Control & Treated & $\%$ change & a & Control & Treated & $\%$ change ${ }^{\text {b }}$ \\
\hline 1 & 18.6 & 18.8 & 19.0 & 12.4 & -34.74 & 353 & 522 & 47.88 \\
\hline 2 & 20.6 & 20.8 & 15.0 & 9.4 & -37.33 & 83 & 274 & 230.12 \\
\hline 3 & 26.7 & 26.8 & 15.7 & 10.7 & -31.85 & 1047 & 385 & -63.23 \\
\hline 4 & 32.8 & 32.9 & 674.0 & 623.0 & -7.57 & 637 & 413 & -35.16 \\
\hline 5 & 33.8 & 33.8 & 81.0 & 89.0 & 9.88 & 414 & 326 & -21.26 \\
\hline 6 & 38.0 & 38.1 & 247.0 & 248.0 & 0.40 & 542 & 416 & -23.25 \\
\hline 7 & 39.7 & 39.7 & 30.0 & 23.0 & -23.33 & 242 & 233 & -3.72 \\
\hline 8 & 54.9 & 54.9 & 158.0 & 148.0 & -6.33 & 519 & 496 & -4.43 \\
\hline 9 & 65.3 & 65.4 & 95.0 & 112.0 & 17.89 & 399 & 403 & 1.00 \\
\hline 10 & \multicolumn{4}{|c|}{ Average crystallite size } & 470.67 & 385.33 & -18.13 \\
\hline
\end{tabular}

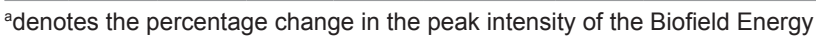
Treated sample with respect to the control sample; 'denotes the percentage change in the crystallite size of the Biofield Energy Treated sample with respect to the control sample.

\section{Materials and Methods}

\section{Chemicals and reagents}

The silver (I) oxide $\left(\mathrm{Ag}_{2} \mathrm{O}\right)$ powder was purchased from Sigma Aldrich, India. All other chemicals used during the experiments were of analytical grade available in India.

\section{Consciousness energy healing treatment strategies}

The test sample (silver oxide) powder was divided into two parts. One part of the test sample was treated with the Trivedi Effect-Consciousness Energy Healing Treatment remotely under standard laboratory conditions for 3 minutes and known as the Biofield Energy Treated sample. The Biofield Energy Treatment was provided through the healer's unique energy transmission process by the renowned Biofield Energy Healer, Alice Branton, USA, to the test sample. Subsequently, the other part of the test sample was considered as a control/untreated sample (Biofield Energy Treatment was not provided). Further, the control sample was treated with a "sham" healer for the comparison with the results of the Biofield Energy Treated silver oxide. The "sham" healer did not aware about the Biofield Energy Treatment. After the treatment, the Biofield Energy Treated and untreated silver oxide samples were kept in sealed conditions and characterized using PXRD, PSA, DSC, and TGA techniques.

\section{Characterization}

The PSA, PXRD, DSC, and TGA analysis of silver oxide were performed. The PXRD analysis of silver oxide powder sample was performed with the help of Rigaku MiniFlex-II Desktop X-ray diffractometer (Japan) [30,31]. The average size of crystallites was calculated from PXRD data using the Scherrer's formula (1):

$$
\mathrm{G}=\mathrm{k} \lambda / \beta \cos \theta
$$

Where $\mathrm{G}$ is the crystallite size in $\mathrm{nm}, \mathrm{k}$ is the equipment constant (0.94), $\lambda$ is the radiation wavelength $(0.154056 \mathrm{~nm}$ for Ka1 emission), $\beta$ is the full-width at half maximum, and $\theta$ is the Bragg angle [32].

The PSA was performed using Malvern Mastersizer 2000, from the UK with a detection range between $0.01 \mu \mathrm{m}$ to $3000 \mu \mathrm{m}$ using the wet method $[33,34]$. Similarly, the DSC analysis of silver oxide was performed with the help of DSC Q200, TA instruments $[28,29]$.
The TGA/DTG thermograms of silver oxide were obtained with the help of TGA Q50 TA instruments [28,29]. The \% change in particle size, Specific Surface Area (SSA), peak intensity, crystallite size, melting point, latent heat, weight loss and the maximum thermal degradation temperature $\left(\mathrm{T}_{\max }\right.$ ) of the Biofield Energy Treated sample was calculated compared with the control sample using the following equation 2:

$$
\% \text { change }=\frac{[\text { Treated-Control }]}{\text { Control }} \times 100
$$

\section{Results and Discussion}

\section{Powder X-ray Diffraction (PXRD) analysis}

The PXRD experimental results of the control and the Biofield Energy Treated silver oxide samples showed sharp and intense peaks in the respective diffractograms indicated that both the samples were crystalline (Figure 1). The peak intensities of the Biofield Energy Treated silver oxide were significantly altered ranging from -37.33 to $17.89 \%$ compared to the control sample (Table 1). Similarly, the crystallite sizes of the Biofield Energy Treated silver oxide were significantly altered ranging from $-63.23 \%$ to $230.12 \%$ compared to the control sample. Overall, the average crystallite size of the Biofield Energy Treated silver oxide $(385.33 \mathrm{~nm})$ was significantly decreased by $18.13 \%$ compared with the control sample $(470.67 \mathrm{~nm})$.

The results indicated significant variations in the crystallite sizes and peak intensities of the Biofield Energy Treated sample compared to the control sample. The literature says that, the peak intensity of any diffraction face on the crystalline compound changes according to the crystal morphology [35], and alterations in the PXRD pattern provides the proof of polymorphic transitions [36,37]. The Biofield Energy Healing Treatment probably produced the new polymorphic form of silver oxide with the help of Consciousness
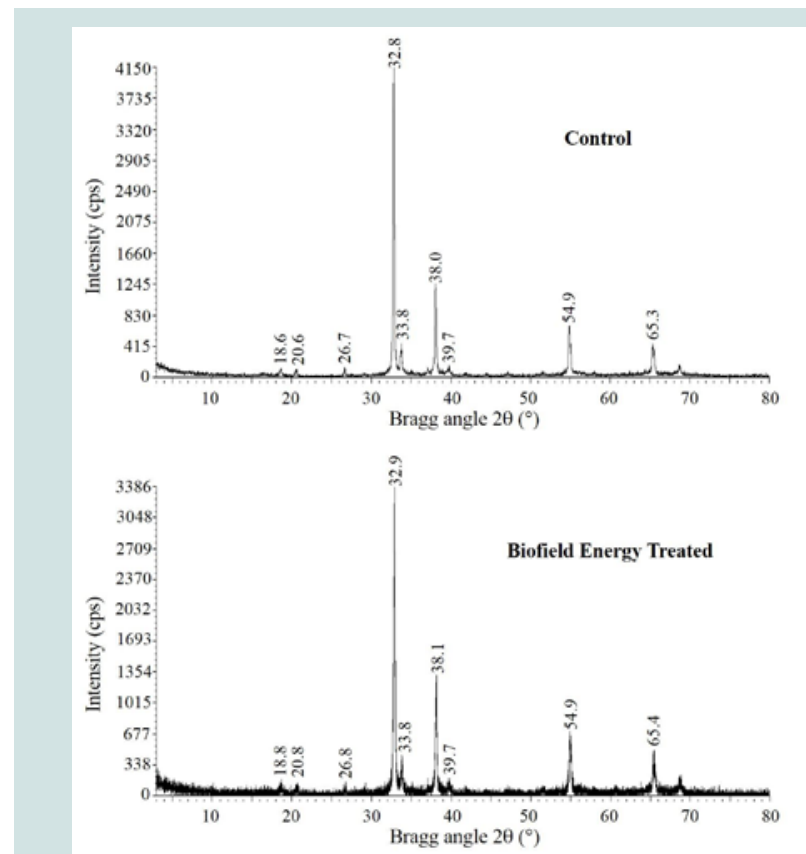

Figure 1: PXRD diffractograms of the control and the Biofield Energy Treated silver oxide. 
Citation: Branton A, Trivedi MK, Trivedi D, Nayak G, Jana S. Evaluation of the Effect of Consciousness Energy Healing Treatment on the Physicochemical and Thermal Properties of Silver Oxide. J Chem Applications. 2018;4(1): 5.
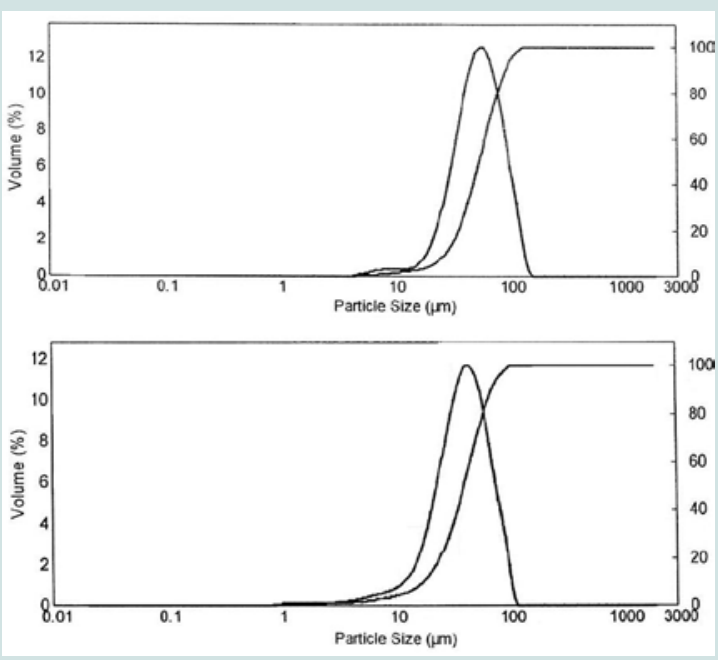

Figure 2: Particle size distribution curve of the control and the Biofield Energy Treated silver oxide.
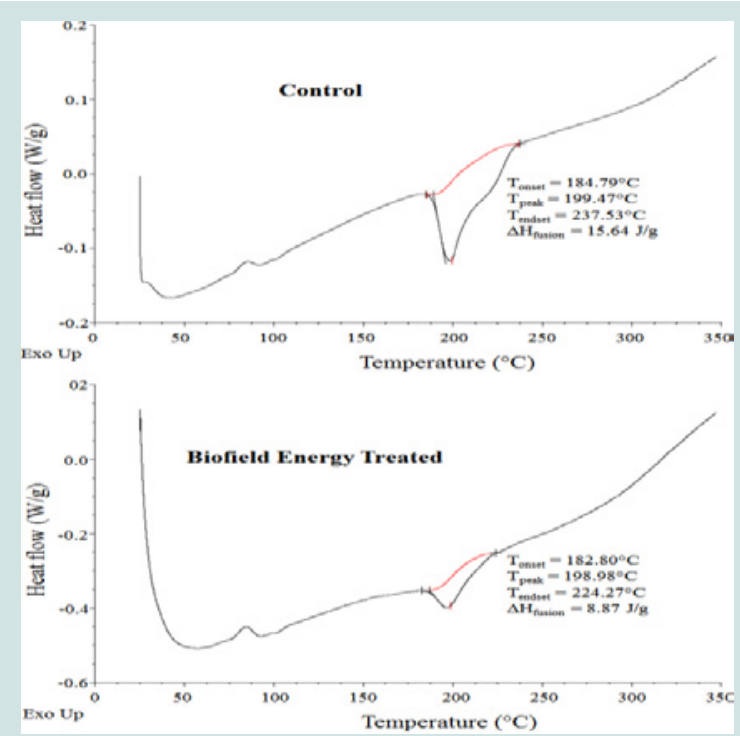

Figure 3: DSC thermograms of the control and Biofield Energy Treated silver oxide.

Energy via neutrino oscillations [10]. Different polymorphic forms of a compound have a significant effect on their physicochemical and thermodynamic properties like melting point, energy, stability, and especially solubility $[38,39]$. Hence, the Trivedi Effect ${ }^{\circ}$ Treated silver oxide would be better to use in the pharmaceutical formulations and other industry using it as a raw material for the manufacturing.

\section{Particle Size Analysis (PSA)}

The PSA analysis of both the control and the Biofield Energy Treated silver oxide was performed, and the distribution curves are presented in (Figure 2). The pattern of particle size distribution curve of the Biofield Energy Treated silver oxide sample was slightly different compared to the control sample (Figure 2). The particle size values of the control sample at $d_{10}, d_{50}, d_{90}$, and $D(4,3)$ were $28.31 \mu \mathrm{m}$, $55.43 \mu \mathrm{m}, 97.26 \mu \mathrm{m}$, and $59.35 \mu \mathrm{m}$, respectively. Similarly, the particle sizes of the Biofield Energy Treated silver oxide at $\mathrm{d}_{10}, \mathrm{~d}_{50}, \mathrm{~d}_{90}$, and $\mathrm{D}(4,3)$ were $18.11 \mu \mathrm{m}, 40.94 \mu \mathrm{m}, 74.44 \mu \mathrm{m}$, and $43.83 \mu \mathrm{m}$, respectively. Therefore, the particle size values in the Biofield Energy Treated silver oxide was significantly decreased at $\mathrm{d}_{10}, \mathrm{~d}_{50}, \mathrm{~d}_{90}$, and $\mathrm{D}(4,3)$ by $36.02 \%, 26.15 \%, 23.46 \%$, and $26.15 \%$, respectively compared to the control sample (Table 2). The specific surface area of the Biofield Energy Treated silver oxide $\left(0.22 \mathrm{~m}^{2} / \mathrm{g}\right)$ was significantly increased by $61.94 \%$ compared with the control sample $\left(0.13 \mathrm{~m}^{2} / \mathrm{g}\right)$. Hence, it can be assumed that the Trivedi Effect-Consciousness Energy Healing Treatment might act as an external force for decreasing the particle sizes of silver oxide sample, hence increased the surface area. It was previously reported that the particle size, shape, and surface area have their impact on the solubility, dissolution rate, absorption, bioavailability, and even the therapeutic efficacy if it is a drug [40-42]. Thus, it is anticipated that the Biofield Energy Treated silver oxide might show the enhanced therapeutic properties of pharmaceutical formulations and would be better for the industry using it as a raw material for the manufacturing.

\section{Differential Scanning Calorimetry (DSC) analysis}

The DSC thermal analysis has been performed to characterize the thermal behavior of both the control and the Biofield Energy Treated silver oxide samples (Figure 3). The thermograms of the control and Biofield Energy Treated silver oxide showed the sharp endothermic peak at $199.74{ }^{\circ} \mathrm{C}$ and $198.98^{\circ} \mathrm{C}$, respectively (Table 3). The experimental melting point match to the reported melting point [1]. The melting point of the Biofield Energy Treated silver oxide was slightly decreased by $0.38 \%$ compared with the control sample (Table $3)$.

The heat energy required to melt (latent heat of fusion; $\Delta \mathrm{H}$ fusion) of the Biofield Energy Treated silver oxide $(8.87 \mathrm{~J} / \mathrm{g})$ was significantly decreased by $43.29 \%$ compared with the control sample $(15.64 \mathrm{~J} / \mathrm{g})$ (Table 3). Any change in the chains of the molecule and the crystal structure change in the latent heat of fusion [43]. Therefore, it can be presumed that Alice's Biofield Energy Treatment disturbed the

Table 2: Particle size distribution of the control and the Biofield Energy Treated silver oxide.

\begin{tabular}{|c|c|c|c|c|c|}
\hline Parameter & $\mathrm{d}_{10}(\mu \mathrm{m})$ & $\mathrm{d}_{50}(\mu \mathrm{m})$ & $\mathrm{d}_{90}(\mu \mathrm{m})$ & $\mathrm{D}(4,3)(\mu \mathrm{m})$ & $\mathrm{SSA}\left(\mathrm{m}^{2} / \mathrm{g}\right)$ \\
\hline Control & 28.31 & 55.43 & 97.26 & 59.35 & 0.134 \\
\hline Biofield Treated & 18.11 & 40.94 & 74.44 & 43.83 & 0.217 \\
\hline Percent change $^{*}(\%)$ & -36.02 & -26.15 & -23.46 & -26.15 & 61.94 \\
\hline
\end{tabular}

$d_{10}, d_{50}$, and $d_{90}$ : particle diameter corresponding to $10 \%, 50 \%$ and $90 \%$ of the cumulative distribution, $\mathrm{D}(4,3)$ : the average mass-volume diameter, and SSA: the specific surface area. "denotes the percentage change in the Particle size distribution of the Biofield Energy Treated sample with respect to the control sample.

Table 3: DSC data for both control and the Biofield Energy Treated samples of silver oxide.

\begin{tabular}{|c|c|c|}
\hline Sample & Melting point $\left({ }^{\circ} \mathbf{C}\right)$ & $\Delta \mathbf{H}(\mathbf{J} / \mathbf{g})$ \\
\hline Control Sample & 199.74 & 15.64 \\
\hline Biofield Energy Treated & 198.98 & 8.87 \\
\hline$\%$ Change $^{*}$ & -0.38 & -43.29 \\
\hline
\end{tabular}

$\Delta \mathrm{H}$ : Latent heat of fusion, ${ }^{*}$ denotes the percentage change of the Biofield Energy Treated silver oxide with respect to the control sample. 
Citation: Branton A, Trivedi MK, Trivedi D, Nayak G, Jana S. Evaluation of the Effect of Consciousness Energy Healing Treatment on the Physicochemical and Thermal Properties of Silver Oxide. J Chem Applications. 2018;4(1): 5.

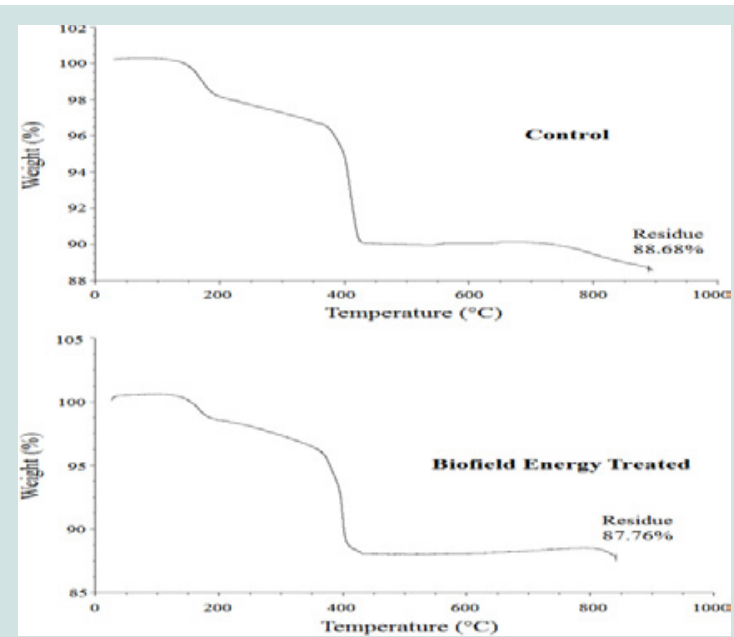

Figure 4: TGA thermograms of the control and the Biofield Energy Treated silver oxide.
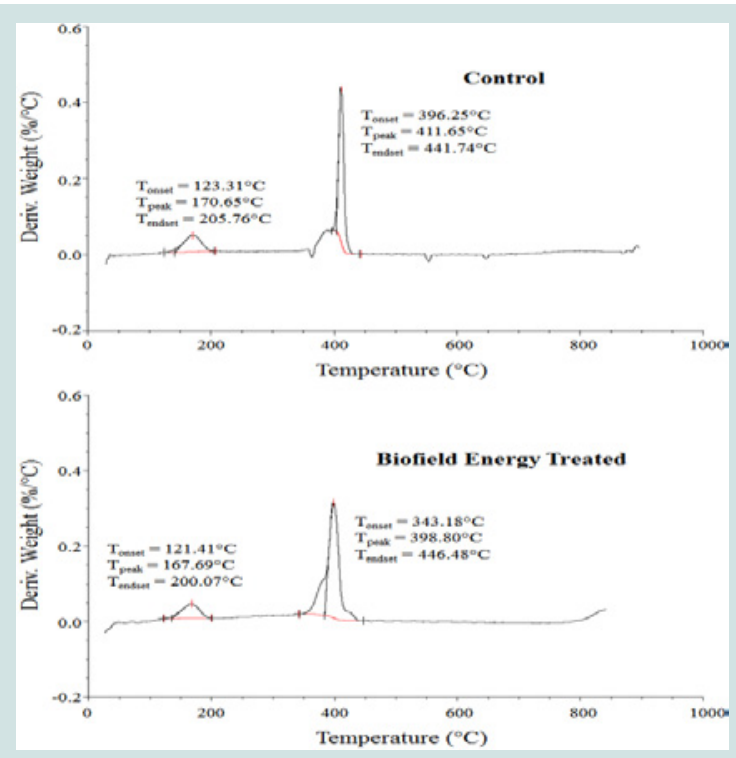

Figure 5: DTG thermograms of the control and the Biofield Energy Treated silver oxide.

molecular chains and crystal structure of silver oxide which would decline the melting point and latent heat of fusion of the treated sample compared to the control sample $[9,10]$.

Thermal Gravimetric Analysis (TGA)/ Differential Thermo Gravimetric Analysis (DTG)

The TGA thermal analysis was performed, and the thermograms of the control and the Biofield Energy Treated silver oxide samples displayed two steps of thermal degradation (Figure 4). The total weight loss in the Biofield Energy Treated silver oxide (12.24\%) was increased significantly by $8.13 \%$ compared with the control sample (11.32\%). Therefore, the residue amount was $1.04 \%$ less in the Biofield Energy Treated silver oxide compared to the control sample (Table 4).

Similarly, the DTG thermograms of the control and the Biofield
Table 4: TGA/DTG data of the control and the Biofield Energy Treated samples of silver oxide.

\begin{tabular}{|c|c|c|c|c|}
\hline \multirow{2}{*}{ Sample } & \multicolumn{2}{|c|}{ TGA } & \multicolumn{2}{c|}{ DTG $\left[T_{\max }\left({ }^{\circ} \mathbf{C}\right)\right]$} \\
\cline { 2 - 5 } & $\begin{array}{c}\text { Total weight loss } \\
(\%)\end{array}$ & Residue \% & 1 $^{\text {st }}$ Peak & 2 $^{\text {nd }}$ Peak \\
\hline Control & 11.32 & 88.68 & 170.65 & 411.65 \\
\hline $\begin{array}{c}\text { Biofield Energy } \\
\text { Treated }\end{array}$ & 12.24 & 87.76 & 167.69 & 398.8 \\
\hline \% Change & 8.13 & -1.04 & -1.73 & -3.12 \\
\hline
\end{tabular}

"denotes the percentage change of the Biofield Energy Treated sample with respect to the control sample,

$\mathrm{T}_{\max }=$ the temperature at which maximum weight loss takes place in TG or peak temperature in DTG.

Energy Treated silver oxide exhibited two peaks (Figure 5). The $\mathrm{T}_{\text {max }}$ of the $1^{\text {st }}$ peak of the Biofield Energy Treated sample was decreased by $1.73 \%$ compared with the control sample. Likewise, the $\mathrm{T}_{\max }$ of the $2^{\text {nd }}$ peak of the Biofield Energy Treated sample was also decreased by $3.12 \%$ compared to the control sample (Table 4 ). Overall, TGA/ DTG revealed that the thermal stability of the Biofield Energy Treated silver oxide was declined compared with the control sample.

\section{Conclusion}

The Trivedi Effect-Consciousness Energy Healing Treatment has shown the significant impact on the crystallite size, particle size, surface area, and thermal behaviors of silver oxide. The PXRD analysis of the control and the Biofield Energy Treated silver oxide showed sharp and intense peaks in the diffractograms, indicated that both the samples were crystalline. The peak intensities and crystallite size of the Biofield Energy Treated silver oxide were significantly altered ranging from -37.33 to $17.89 \%$ and $-63.23 \%$ to $230.12 \%$, respectively, compared with the control sample. Overall, the average crystallite size of the Biofield Energy Treated silver oxide was significantly decreased by $18.13 \%$ compared with the control sample. The particle size values of the Biofield Energy Treated silver oxide were significantly decreased at $\mathrm{d}_{10}, \mathrm{~d}_{50}, \mathrm{~d}_{90}$, and $\mathrm{D}(4,3)$ by $36.02 \%, 26.15 \%, 23.46 \%$, and $26.15 \%$, respectively compared to the control sample. Therefore, the specific surface area of the Biofield Energy Treated silver oxide was significantly increased by $61.94 \%$ compared with the control sample. The $\Delta \mathrm{H}_{\text {fusion }}$ the Biofield Energy Treated silver oxide was significantly decreased by $43.29 \%$ compared with the control sample. The total weight loss was increased by $8.13 \%$ compared with the control sample. The Trivedi Effect'-Consciousness Energy Healing Treatment introduced a new polymorphic form of silver oxide which may show better solubility, dissolution rate, absorption, and bioavailability toxicity of silver oxide in the pharmaceutical formulations and advantageous for the industry using it as a raw material.

\section{References}

1. Allahverdiyev AM, Abamor ES, Bagirova M, Rafailovich M (2011) Antimicrobial effects of $\mathrm{TiO}(2)$ and $\mathrm{Ag}(2) \mathrm{O}$ nanoparticles against drug-resistant bacteria and Leishmania parasites. Future Microbiol 6: 933-940.

2. Akiyama T, Miyamoto H, Yonekura Y, Tsukamoto M, Ando Y, et al. (2013) Silver oxide-containing hydroxyapatite coating has in vivo antibacterial activity in the rat tibia. J Orthop Res 31:1195-200.

3. (2013) MSDS - Silver Oxide.

4. Belcaro G, Cesarone MR, Errichi BM, Ricci A, Antelman P, et al. (2011) Silver oxide ointment wound dressing in venous ulcerations: home, selfmanagement. Panminerva Med 53: 29-33. 
Citation: Branton A, Trivedi MK, Trivedi D, Nayak G, Jana S. Evaluation of the Effect of Consciousness Energy Healing Treatment on the Physicochemical and Thermal Properties of Silver Oxide. J Chem Applications. 2018;4(1): 5

5. Michael, Ash I (2004) Handbook of Preservatives. Synapse Information Resources Inc. Endicott, NY, 522

6. Hassan MAM, Agool IR, Raoof LM (2014) Silver oxide nanostructure prepared on porous silicon for optoelectronic application. Appl Nano Sci 4: 429-447.

7. Trivedi MK, Branton A, Trivedi D, Nayak G, Gangwar M, et al. (2015) Effect of biofield energy treatment on chlorophyll content, pathological study, and molecular analysis of cashew plant (Anacardium occidentale L.). J Plant Sci 3: $372-382$.

8. Trivedi MK, Branton A, Trivedi D, Shettigar H, Nayak G, et al. (2015) Assessment of antibiogram of multidrug-resistant isolates of Enterobacter aerogenes after biofield energy treatment. J Pharma Care Health Sys 2: 145

9. Dabhade VV, Tallapragada RMR, Trivedi MK (2009) Effect of external energy on the atomic, crystalline, and powder characteristics of antimony and bismuth powders. Bull Mate Sci 32: 471-479.

10. Trivedi MK, Mohan TR (2016) Biofield energy signals, energy transmission and neutrinos. Am J Mod Phy 5: 172-176.

11. Rubik B, Muehsam D, Hammerschlag R, Jain S (2015) Biofield science and healing: history, terminology, and concepts. Glob Adv Health Med 4: 8-14.

12. Barnes PM, Bloom B, Nahin RL (2008) Complementary and alternative medicine use among adults and children: United States, 2007. Natl Health Stat Report 12: 1-23

13. Koithan M (2009) Introducing complementary and alternative therapies. $J$ Nurse Pract 5: 18-20.

14. Trivedi MK, Branton A, Trivedi D, Nayak G, Mondal SC, et al. (2015) Evaluation of plant growth, yield and yield attributes of biofield energy treated mustard (Brassica juncea) and chick pea (Cicer Arietinum) Seeds. Agri For and Fish 4: 291-295.

15. Trivedi MK, Branton A, Trivedi D, Nayak G, Gangwar M, et al. (2015) Evaluation of vegetative growth parameters in biofield treated bottle gourd (Lagenaria siceraria) and Okra (Abelmoschus esculentus). Int J Nutr Food Sci 4: 688-694.

16. Trivedi MK, Branton A, Trivedi D, Nayak G, Mondal SC et al. (2015) Antimicrobial sensitivity, biochemical characteristics and biotyping of Staphylococcus saprophyticus: An impact of biofield energy treatment. J Women's Health Care 4: 271.

17. Trivedi MK, Branton A, Trivedi D, Nayak G, Shettigar H, et al. (2015) Antibiogram of multidrug-resistant isolates of Pseudomonas aeruginosa after biofield treatment. J Infect Dis Ther 3: 244.

18. Trivedi MK, Branton A, Trivedi D, Nayak G, Mondal SC, et al. (2015) Evaluation of plant growth regulator, immunity and DNA fingerprinting of biofield energy treated mustard seeds (Brassica juncea). Agri for Fish. 4: 269-274.

19. Trivedi MK, Branton A, Trivedi D, Nayak G, Bairwa K, et al. (2015) Physical, thermal, and spectroscopic characterization of biofield energy treated murashige and skoog plant cell culture media. Cell Biology 3: 50-57.

20. Trivedi MK, Branton A, Trivedi D, Nayak G, Panda P, et al. (2016) Isotopic abundance ratio analysis of 1,2,3-trimethoxybenzene (TMB) after biofield energy treatment (The Trivedi Effect ${ }^{\circledR}$ ) using gas chromatography-mass spectrometry, Am J Appl Chem 4: 132-140.

21. Trivedi MK, Branton A, Trivedi D, Nayak G, Panda P, et al. (2016) Gas chromatography-mass spectrometric analysis of isotopic abundance of $13 \mathrm{C}$ $2 \mathrm{H}$, and 180 in biofield energy treated $p$-tertiary butylphenol (PTBP). Am J Chem Eng 4: 78-86.

22. Trivedi MK, Patil S, Tallapragada RM (2013) Effect of biofield treatment on the physical and thermal characteristics of Silicon, Tin and Lead powders. $J$ Material Sci Eng 2:125.

23. Trivedi MK, Patil S, Tallapragada RM (2013) Effect of bio field treatment on the physical and thermal characteristics of vanadium pentoxide powders. $J$ Material Sci Eng S: 11

24. Trivedi MK, Patil S, Shettigar H, Mondal SC, Jana S, et al. (2015) The potential impact of biofield treatment on human brain tumor cells: A timelapse video microscopy. J Integr Oncol 4: 141.
25. Trivedi MK, Patil S, Shettigar H, Gangwar M, Jana S, et al. (2015) in vitro evaluation of biofield treatment on cancer biomarkers involved in endometrial and prostate cancer cell lines. J Cancer Sci Ther 7: 253-257.

26. Jana S, Trivedi MK, Tallapragada RM, Branton A, Trivedi D, et al. (2015) Characterization of physicochemical and thermal properties of chitosan and sodium alginate after biofield treatment. Pharm Anal Acta 6: 430.

27. Trivedi MK, Patil S, Shettigar H, Bairwa K, Jana S (2015) Spectroscopic characterization of chloramphenicol and tetracycline: An impact of biofield. Pharm Anal Acta 6: 395.

28. Branton A, Jana S (2017) Effect of The biofield energy healing treatment on the pharmacokinetics of 25-hydroxyvitamin D3 $\left[25(\mathrm{Oh}) \mathrm{D}_{3}\right]$ in rats after a single oral dose of vitamin $D_{3}$. Am J Pharm and Phytother 2: 11-18.

29. Branton A, Jana S (2017) The influence of energy of consciousness healing treatment on low bioavailable resveratrol in male Sprague Dawley rats. Intern $\mathrm{J}$ Clin and Dev Anat 3: 9-15.

30. Desktop X-ray Diffractometer "MiniFlex+" (1997) The Rigaku Journal 14: 2936

31. Zhang T, Paluch K, Scalabrino G, Frankish N, Healy AM, et al. (2015) Molecular structure studies of (1S,2S)-2-benzyl-2,3-dihydro-2-(1Hinden-2yl)-1H-inden-1-ol. J Mol Struct 1083: 286-299.

32. Langford JI, Wilson AJC (1978) Scherrer after sixty years: A survey and some new results in the determination of crystallite size. J Appl Cryst 11: 102-113.

33. Trivedi MK, Sethi KK, Panda P, Jana S (2017) A comprehensive physicochemical, thermal, and spectroscopic characterization of zinc (II) chloride using X-ray diffraction, particle size distribution, differential scanning calorimetry, thermogravimetric analysis/differential thermogravimetric analysis, ultraviolet-visible, and Fourier transform-infrared spectroscopy. Int J Pharm Investig 7: 33-40.

34. Trivedi MK, Sethi KK, Panda P, Jana S (2017) Physicochemical, thermal and spectroscopic characterization of sodium selenate using XRD, PSD, DSC TGA/DTG, UV-vis, and FT-IR. Marmara Pharma J 21: 311-318.

35. Inoue M, Hirasawa I (2013) The relationship between crystal morphology and XRD peak intensity on $\mathrm{CaSO}_{4} \cdot 2 \mathrm{H}_{2} \mathrm{O}$. J Crystal Growth 380: 169-175

36. Raza K, Kumar P, Ratan S, Malik R, Arora S (2014) Polymorphism: The phenomenon affecting the performance of drugs. SOJ Pharm Pharm Sci 1: 10.

37. Brittain HG (2009) Polymorphism in pharmaceutical solids in Drugs and Pharmaceutical Sciences, volume 192, 2nd Edn, Informa Healthcare USA Inc., New York.

38. Censi R, Martino PD (2015) Polymorph Impact on the Bioavailability and Stability of Poorly Soluble Drugs. Molecules 20: 18759-18776.

39. Blagden N, de Matas M, Gavan PT, York P (2007) Crystal engineering of active pharmaceutical ingredients to improve solubility and dissolution rates. Adv Drug Deliv Rev 59: 617-630.

40. Chereson R (2009) Bioavailability, bioequivalence, and drug selection. In: Makoid CM, Vuchetich PJ, Banakar UV (Eds) Basic pharmacokinetics $\left(1^{\mathrm{st}}\right.$ Edn) Pharmaceutical Press, London.

41. Khadka P, Ro J, Kim H, Kim I, Kim JT, et al. (2014) Pharmaceutical particle technologies: An approach to improve drug solubility, dissolution and bioavailability. Asian J Pharm Sci 9: 304-316.

42. Buckton G, Beezer AE (1992) The relationship between particle size and solubility. Int J Pharmaceutics 82: R7-R10.

43. Zhao Z, Xie M, Li Y, Chen A, Li G, et al. (2015) Formation of curcumin nanoparticles via solution-enhanced dispersion by supercritical $\mathrm{CO}_{2}$. Int $\mathrm{J}$ Nanomedicine 10: 3171-3181.

\section{Acknowledgement}

The authors are grateful to Central Leather Research Institute, SIPRA Lab. Ltd., Trivedi Science, Trivedi Global, Inc., Trivedi Testimonials, and Trivedi Master Wellness for their assistance and support during this work 